\title{
Gender and Conflict Management: The Role of Women's in Indigenous Conflict Resolutions for Peace Building in Ethiopia: A Systematic Review and Meta-Analysis
}

\author{
Eyayu Kasseye Bayu \\ Department of Gender and Development Studies, College of Social Science and Humanities, University of \\ Gondar, Ethiopia
}

\begin{abstract}
Evidence from around the world and across cultures showed that integrating women and gender considerations into peace-building processes helps to promote democracy, good governance, long-term stability and development. The inclusion of gender perspectives into conflict analyses can be beneficial not only to ensure better understanding of conflict dynamics, but also to highlight the linkages with development and poverty issues. Hence, the current review is aims to assess the role of women's in indigenous conflict resolution in different regions of Ethiopia. All available materials were reviewed. The results of the review disclosed that even if women's formal participation in the highest leadership positions were formally closed, it is documented that throughout the world, women had played critical roles in times of wars and peace as community organizers and activists. The findings further showed that the role and participation of women in the indigenous conflict management mechanisms is low and insignificant in Tigray. In indigenous system, women play an indirect role in Amhara and Tigray. In Oromia region, women have a great role in solving conflicts among Oromo clans by intervene and request for reconciliation by using the institution called Siqqe. They also have the right and power to reconcile Oromo people to their God called Waqqa by praying to God for them. In Somalia, Women's also play multiple roles before, during and after conflicts. Women of South nations and nationality play different roles in addressing conflicts either along with men or alone and the male based institutions address conflicts in equal basis irrespective of sex. Based on the above findings, it can be concluded that, Ethiopian women's play a pivotal role and still working to maintain peace and security across all provinces of the country. Therefore, women should be respected as they have a lion share role in indigenous conflict resolutions as well as they should be empowered to involve in peace promotion and peacemaking at regional and country level.
\end{abstract}

Keywords: Gender, Indigenous, Conflict resolutions, Peace building, Ethiopia

DOI: $10.7176 / \mathrm{IAGS} / 80-01$

Publication date: February $29^{\text {th }} 2020$

\section{Introduction and Background}

Conflict has been studied by different scholars over the past centuries. However, still now there is no agreement upon the definition of the term. This is because conflicts vary considerably depending on the culture of a given society. As to Fisher (2000) conflict is defined as an incompatibility of goals or values between two or more parties in a relationship combined with attempts to control each other and antagonistic feelings towards each other. Similarly, Mesfin (1999) stated that conflict is a practice of disagreement on public issues that affect the lives of groups essentially about means and ends regarding their mutual relationships their diverse interests their different values their institutions and organizations. Parallel to the above point, Chandan (1995) defined conflict as a disagreement between or among two or more nations, individuals, groups and organizations trying to gain acceptance of one's views or objectives over the others. Generally, based on the above arguments conflict could be conceptualized as contradiction or disagreement between two or more parties arising from misunderstandings, competition for resource, power and prestige.

But, the experience in human society has shown that, there are degrees of variation in conflicts. Conflicts are in types such as intra-personal conflict, inter-personal conflict, inter-group conflict, family conflict, intraState conflict and inter-State conflict (Sheriff, n.d). According to Dragos (2012), a conflict has always a cause which determines the nature and intensity of that conflict including possible sources of conflict such as: poor communication, competition for common but limited resources, incompatible purposes and desires, inequality and social discrimination, access to competitive opportunities or increased desire for domination, power or prestige. Conflict takes various forms. That is, its nature varies substantially ranging from peaceful expression of grievance to outright use of physical force or violence. More specifically, depending on the prevailing circumstances, the parties involved in the conflict and the means preferred to settle disputes or conflict varies from relatively peaceful institutionalized ethnic conflict to violent struggle, civil war and ethnic cleansing (Hussein, 2005).

In other words, conflict is classified as destructive and constructive. Constructive conflicts open up an issue in a confronting manner, develop clarification of an issue, improve problem solving equality, increase 
involvement and provide more spontaneity in communication, initiate growth and strengthen a relationship and increase productivity (Ratzburg cited in Birhanu, 2010). Moreover, in a constructive conflict resolution, partners focus on current rather than past issues, share both positive and negative feelings, provide information in an open manner, accept mutual blame and search for similarities. Both partners win and as a result intimacy increases and trust grows in the relationship (Olsen and Defrain, 2000).

On the other hand, destructive conflicts divert energy from real task, destroy morale, polarize individuals and groups and deepen differences, obstruct cooperative actions, produce irresponsible behaviors, create suspicious and distrust decrease productivity (Ratzburg cited in Birhanu, 2010). As to Olsen and Defrain (2000), in destructive approaches to conflict resolution, partner bring up old issues, express only negative feelings, reveal selective information, focus on people rather than on issues and emphasize differences all with the goal of minimizing change. There are also some scholars who refrain from generalizing conflict as constructive and destructive. They prefers to take the neutral position. The basic assumption of the social frame of reference is that conflict is natural and inevitable in all human interaction. Because of the wide range of potential differences among people, the absence of conflict usually signals the absence of meaningful interaction. However, the manner in which conflict is handled determines whether it is constructive or destructive (Eshleman and Wilson, 1995).

\section{Consequence of Conflict}

Countries suffer from many different consequences of violent conflict. Violent conflict kills people in different ways although it is often difficult to estimate how many. Civilians and soldiers are killed in combat; people die because of a higher prevalence of diseases and an increase in violent crime. Wars forces to mass migration and has economic consequences. It leads to unemployment and loss of income owing to disruption of economic activity, destruction of infrastructure, uncertainty, increased cost of doing business, and capital flight (African Development Bank, 2008). Generally, due to the arguments on the constructive and destructive nature of conflict, one can understand that conflict is neither always constructive nor destructive. Conflict management is the process of reducing the negative and destructive capacity of conflicts through a number of measures and by working with and through the parties involved in the conflict (Best, 2004. While conflict is universal, the ways in which it is expressed and handled are not. If we are to learn how to deal with conflict effectively (our own and others), it is necessary for us to understand our cultural assumptions about conflict and conflict resolution mechanisms (Kifle, 2007).

\section{Types of Conflict Handling Methods in the World}

The source of conflict handling is conflict by itself. It is therefore natural to expect that different types of conflict and different sources of conflict will lead to different types of conflict handling. As Jens (1993) noted, there is a universal tendency to try to get rid of conflict when it arises. The means chosen to do so might, however, have the opposite effects. He suggests five types of conflict handling can be distinguished: Prevention of conflict (conflict can be prevented by taking action, before an actual conflict has developed, to prevent conflict generating features from occurring). Some of the methods for doing this consist in encouraging mutual consideration and building mutual obligations. Secondly, avoidance of conflict refers to a case in which conflict action is expected (because of actual conflict generating features or experienced grounds for conflict), but does not in fact occur. In the third ways, compromise is a symmetrically regulated type of conflict handling, where all parties inhibit their claims and demands to some degree, so that mutual compatibility between the claims or occur when conflict is terminated by one party. Last but not least, competition is thus a way of regulating conflict with the goal of restricted dominance and submission. If the conflict is unrestricted (as in war) victory, defeat and extermination appear as other ways in which conflict can be terminated. It implies that, a conflict is resolved if the experienced causes for the conflict are removed. Resolving a conflict, thus, often involves changing attitudes of revenge and hatred by excusing and forgiving the other party (Burton, 1987).

\section{What is Conflict Resolution in the World?}

Principally, traditional conflict resolution mechanism is a social capital that can be defined as the capability of social norms and customs to hold members of a group together by effectively setting and facilitating the terms of their relationship and sustainability facilitates collective action for achieving mutually beneficial ends (FredMensah, 2005:1). Traditional conflict resolution is a structured political, judicial and arbitration mechanism. Traditional leaders play a vital role in local and grassroots communities in relation to socio-economic development and the administration of justice in the modern political system.It plays two important roles: a proactive role to promote social cohesion, peace, harmony, coexistence and a reactive role in resolving disputes which have already occurred (Department of Justice and Constitutional Development, 2008:30).

Over the years, there have developed inter-group conflict over land; increasing reliance on formal contracts to regulate relationships and create understanding, and shifts in methods of conflict resolution in that mediation 
seems to have given way to more confrontational statutory approaches based on formal court procedures (FredMensah, 2005). Despite these, traditional methods still prevail especially at the grassroots level. Conflict resolution comprises a complex network of forces surrounding the parties in the conflict. It is a healing process in which all stakeholders contribute positive energy. The task is to re-establish the energy flow within individuals, families and communities so as to re-build social harmony. In this context, reconciliation often requires symbolic gestures and associated rituals including exchange of gifts, and slaughter of animals (chickens, goats, sheep, cows) (Ndumbe III, 2001).

As Commonwealth of Australia (2015) indicated, the women, peace and security agenda and national action plan provide Australia with a holistic approach. Both are organized conceptually around these five themes such as conflict prevention, participation, protection, relief and recovery, and normative work. Australia recognizes that coordinated efforts across all themes are critical to address the root causes of conflict and create sustainable peace.

The study conducted by Kwaku etal (n.d) demonstrated the importance of cultural processes, institutions, and values in conflict resolution and peace building among the Akans of Ghana and the Tswana of Botswana. Historically, women's participation in politics and decision-making in Rwanda has been insignificant specifically in high echelons although in the pre-colonial period. Women in Rwanda played an important role in the country's governance through the institution of the queen mother; after the destructive genocide of 1994. Rwandese women in different positions of leadership played critical roles in mobilizing fellow women to live together and to find common solutions to their own problems and those of their country (John and Jeanne, 2005).

The findings of John and Jeanne (2005) also stipulated that women's contribution to peace and reconciliation has been considerable and in many cases unprecedented. "Women's contribution to peace building and reconciliation is still hampered by constraints such as abject poverty, gender based violence, poor organizational capacity among women, limited motivation and facilitation of women initiative”. Peace and reconciliation programs remain largely centralized and not adequately coordinated. Women have a strong potential for educating their children and imparting on them positive cultural values that enhance peace and reconciliation. In areas where women have come together and worked towards reconciliation; their children have spontaneously followed their examples women have a big role to provide basic education and up bringing for children to embrace the culture of peace. This forms the basis of women working towards and promoting sustainable peace: the same is true in Ethiopia.

\section{METHODOLOGY}

In this review, all relevant and available documents reviewed in related with the roles of women in indigenous conflict resolution in different regions of Ethiopia were identified and document review was undertaken from different studies. The main sources considered in the document review were books, journals, policy and strategies documents, studies conducted in line with indigenous conflict resolutions and gender issues. Relevant studies of the identified documents were arranged following an initial assessment of their titles and abstracts or summary. The qualitative data was comprehensively and comparatively analyzed using documenting analysis. Different available qualitative studies regarding the issues are reviewed based on the context where is accessible in different link and open access. The qualitative data is for the purposes of indicating the point of views or perspectives regarding the issues from different studies.

\section{RESULTS AND DISCUSSION}

Ethiopia is a country in which various ethnic groups live together. Each ethnic group has its own way of resolving conflicts. Different communities have distinct traditional settings and relationships where a customary mechanism could play a significant role in resolving and preventing violent conflicts (Mellese,2008). Ambaye (2008) stated that there are customary mechanisms of conflict resolution, which are most often ignored or abandoned with the rise of "modernity". Despite their wide spread use, the customary conflict mechanisms have been received surprisingly little attention by Ethiopian researchers. Traditional approaches of management vary considerably from society to society, from region to region and from community to community. There are many customary approaches to conflict resolution mechanisms, as there are different societies and communities with a specific customs in the world (Yasin, 2010).

Ethiopian societies apply different customary mechanisms to resolve or manage the diverse forms of conflict that arise within their ethnic groups communities. In confirming the above idea, Ephraim in Tarekegn (2008) reported that throughout Ethiopia, among the Arsi Oromo (Jarsabiyya ${ }^{l}$ ), the Amhara (Yeager-Shimagle ${ }^{2}$, the Gurage (Yejewoka-Shengo ${ }^{3}$ ), the Wolayita $\left(\right.$ Deira Cimma $^{l}$ ) and other linguistic or ethnic groups looked up to

\footnotetext{
${ }^{1}$ Jarsabiyya- conflict resolution system in Arsi Oromo

${ }^{2}$ Yager Shimagle- conflict resolution system in Amhara Region

${ }^{3}$ Yejewoka-Shengo- conflict resolution system in Gurage Zone
} 
and their role in reconciliation is highly regarded. The issue of conflict and its resolution is further elaborated by referring to practical examples from the different nations and nationalities of Ethiopia. For example, Tsega (2005) conducted his study on Luba-Basa and Harama- Hodha: Traditional Mechanisms for conflict Resolution in Metekel, West Gojjam. The word "Luba-Basa" is translated as liberating or making free while the word "HarmaHodha" refers to sucking at the breast. The writer in his finding showed that, if refurbished, these institutions can be of a paramount importance to policy makers and practitioners. He further added these institutions are intra as well as inter-ethnic conflict resolution principles and are widely applied in many parts of Ethiopia and can even meet demands outside Africa.

Similarly, a research carried out by Uthman (2008) on the role of the Abegar (Divine father) in conflict resolution the case of Northern Wollo indicated that the Abegar institutions utilize a great variety of schemes and approaches for inter-personal or inter-group compromise for sustainable solutions to conflicts as it is not a top down approach but rather bottom up. On top this, indigenous conflict management mechanisms are by far a better alternative for conflict management. This is because at national level the formal court structures are often unable to provide access to justice for the disputants timely. In response to these and other related problems, different ethnic groups or communities develop their own systems as a way of handling conflicts. For example, among the Tigrians in general and Erob community in particular, there were and still are indigenous mechanisms of conflict management techniques. The ability to successfully manage conflict within one self and between persons reduces antagonism, disagreement and dislike. How a person manages his inner conflict has a direct impact on how he/she lives and deals with others.

\section{Role of Women's in Indigiounous Conflict Resolution in Ethiopia}

Literatures describe that even if women's formal participation in the highest leadership position was formally closed, it is documented that throughout the world, women had played critical roles in times of wars and peace as community organizers and activists. Above all, for instance, in Ethiopian women history, the contributions and brilliant leadership role which have Emperor Minilik's (1877-1913) first formal wife, Bafena and second legal wife Empress Taitu had played is unforgettable history and comes first when one talk about Ethiopian women contributions. For instance, Taitu was acted as the chief advisor of Emperor with particular influence in the area of foreign relations. She holds high profile in the history for patriotism and uncompromisingly pursuing Ethiopia's independence (Meaza, 2009 cited in Endale, 2014).

\section{Role of Women's in Traditional Conflict Resolution in Tigray Region}

Regarding the conception of conflict, a study findings stipulate that conflict both as an inevitable and natural which could prevail in any society and viewed it as bad and destructive. The types of conflicts presented and resolved in the study community are inter-personal, inter-group and inter-ethnic in nature which stemmed from competition over resources, violation of social values, drunkenness and extra sexual relationship with married women and unmarried girls (Solomon, 2014).

The findings showed that the role and participation of women in the indigenous conflict management mechanisms is low and insignificant. The findings of this study revealed that accessibility, restorative capacity, revealing crime committed under cover and acceptability as a major strengths of the system. On the contrary, economic extravagancy, time consuming or prolongation of appointments and exclusion of women from participation in conflict management are identified as the most glaring weaknesses of the system. A study of Solomon also showed in Erob custom, women do not directly serve as community elders (Aruha). Rather, the indigenous system has designed a mechanism for women to participate in the dispute resolution process. Erob women exercise power indirectly and informally as sisters, mothers and wives within their community. And these shows though women have the right to assist (advise) male members of their lineage in times of hardship, they have little room to play leadership roles (representing as Aruha) in resolving communal conflicts.

In indigenous system women play an indirect role. This is because we inherited a similar trend from our ancestors. Despite the fact that women are indirectly participated in the reconciliation process, there is a parallel role of women i.e. providing ideas and views. Furthermore, in case of homicide reconciliation, women have a special duty in the ritual process so as to prepare food and local drinks for the reconciliation process. The major barriers hindering women from public leadership and decision-making positions include: Socio-cultural attitudes and lack of acquisition of the necessary experience for taking part in public decision-making (ibid). Additionally, Tsegay (2003) in his study on "Ethno-Historical Survey of the Erob- Agro-pastoralists" pointed out that Erob had self-contained conflict management that sustained local inter-communal relations for centuries.

Role of Women's in Traditional Conflict Resolution in Oromia Region

Muchie and Bayeh (2015) study indicated that conflicts in Ambo are emanated from various sources. These

\footnotetext{
${ }^{1}$ Deira Cimma- conflict resolution system in Wolayita Zone
} 
factors, inter alia, are associated with competition over grazing land and water resources, boundary conflicts on farm lands, problems of access to water irrigation, sense of superiority, and women's abduction. Accordingly, conflicts have been resolved through knowledgeable and respected elders, religious leaders, and marriage relationships, ceremonies observed by the community, women reconciliation mechanisms, and highly respected and feared clan leaders. In the regional state of Oromo, women also have a great role in solving conflicts among Oromo clans by intervene and request for reconciliation by using the institution called Siqqe ${ }^{l}$. They also have the right and power to reconcile Oromo people to their God called Waqqa ${ }^{2}$ by praying to God for them.

The finding in the study of Muchie(2015) indicates that the majority of clan leaders, religious fathers, community elders, local leaders and conflict resolution experts, illustrate that traditional conflict resolution mechanisms have been widely practiced in West Shewa Zone. The traditional conflict resolution mechanisms have so many advantages compared with the modern court system in terms of cost effectiveness and time and energy saving as they are undertaken out of work time in the morning and near the residential area. Moreover, they have also relatively a permanent or sustainable solution for conflicting parties.

\section{The Role of Women's in Stabilizing Peace in Eastern Ethiopia}

Women's play double roles before, during and after conflicts since they have special skills in instigating conflicts as well as in stabilizing and searching for peace.

Bamlaku etal.,(2010) showed that women play double roles in times of conflicts, i.e. they have skills of promoting conflict as well as of stabilizing situations and searching for peace in the system of indigenous conflict resolution mechanisms among the Issa and Gurgura communities of Somali. They play roles in the formation of social capital through marriage and kinship relations. Women have always been the center for integration - through marriages that brought together and cemented two different and distant clans. They play vital roles for the sustainability of peace building and conflict resolution.

Before conflict: Women praise victory and success as fruits of peace in order to promote peace and stability instead of enmity. Their ideological propaganda in the community to prevent conflict is important. During conflict: A better understanding of the role of women in the search for peace in Somali begins with a clear understanding of their status and role in their society. In a polygamous marriage, the first wife is the chief mediator of conflicts in the family. She is responsible for restoring peace and tranquility in situations of conflict between the husband and one of his wives, or among the latter. She also ensures that perfect harmony exists between the young brothers-in-law and their wives. Women are also able to persuade their husbands, sons, brothers and fathers to stop fighting and settle their cases through negotiation. Women have special skills and power in settling conflicts. There are common proverbs and sayings of Somali women about this: Dagaal wiilbaa ku dhinte ee wilbaa ku dhinta (Males will die and not be born on the battle field.) Furthermore, women constitute a symbol of peace and cooperation. First, a woman promotes understanding between herself and her husband. Second, she bonds her family and her husband's family (Bamlaku etal, 2010).

After conflict: Women also practice the "heerin" tradition, which means unmarried women visit the enemy clan without the permission of their parents. The enemy clan welcomes and will arrange a marriage with them. This enables the two distant and enemy clans to bring together and build sustainable peace and stability. The Somali women have always been the center for integration through marriage that brought together and cemented two different and distant clans (Elster, 1989).

A Somali proverb emphasizes their unique role: 'Only a woman can bring two separate clans together'. When two clans are connecting through marriage, it is the married woman who forms the backbone of the newly established community. She becomes an ambassador of her clan. Somalis say: 'A married woman is an ambassador'. They also say: 'A married woman is a leader'. The bridge she builds between the two communities is one that brings about unity and cooperation (Mohamed, 2003:101).

There are ritual practices and ceremonies observed by the community, especially when there are $A b b a r^{3}$ (drought conditions), war catastrophes, epidemic diseases, or other natural or manmade calamities in their environs. For such cases they have gatherings near rivers. From different areas, they assemble at a place called Mewula $^{4}$ (a place where water and shade are available and where it looks green) to appeal to their God. In this ceremony they pray to and beg their God by slaughtering cattle and chewing chat (a stimulating leaf). In these social gatherings the disputants forgive each other and unite as one.

\section{The Role of Women in Indigenous Conflict resolution in Southern Ethiopia}

From SNNP (South Nations, Nationalities and People of Ethiopia), Sidama society possesses four types of

\footnotetext{
${ }^{1}$ Siqqee-Women institution used for resolving conflict

${ }^{2}$ Waqqa- Praying for God among Oromo people

3 Abbar- Ritual ceremonies among Somali community when drought occur

${ }^{4}$ Mewula- a place where water and Shade are available(Green area)
} 
indigenous or traditional conflict resolution institutions. These are: "Woma" (Hamlet level institution), "Gaanna" (Sub-clan institution), "Karichcha" (Clan level institution) and "Garo" (General assembles of clan level institution (Abebe, 2016). The basic criteria for the classification are due to their geographical proximity and kinship variation to be indigenous conflict resolution mechanism institutions in Sidama society. The most common conflict issues in Sidama are grazing land, water, farmland and borderland. Abebe (2016) study findings showed that Sidama indigenous/traditional institutions played a great role to maintain peace and security within a given community. Therefore, indigenous institutions in Sidama society are still widely exist and respected within Sidama culture. Sidama indigenous institutions have played a great role to solve different local conflicts and for the development of modern institutions. Abebe etal., (2015) indicated that there are different traditional institutions to solve the conflicts among Kembata societies such as Reeda and Gudagambela tradition. These local systems of conflict resolution among the Kembata are the most preferable one. Family is one of the central institutions among the Kembata. The Kembata call the father as abbaa (father of the house) and the mother as Ammaa (mother of the house). Male as Abbaa is the head of the household who is an authority figure and plays a key managerial role. At a clan level, according to Kuwee (1997), women are considered outsiders and are not members of both the clan into which they were born and into which they were married. As opposed to this, in principle, the Kembata women are given full lineage membership. They have the right to claim help and the duties to assist in time of hardship on an equal basis with male members of their lineage. However, the Kembata attach greater value to sons than daughters. This mainly stems from two assumptions: firstly, the continuity of patrilineal descent line, which deserves high value, is possible only through sons.

Secondly, daughters are married and they become outsiders as opposed to sons who look after their parents and their belongings, especially in the latter age. It is commonly said that women are restricted to domestic work and are excluded from public activities, including conflict resolution. In this regard, the Kembata women in play a key role in averting an escalating conflict by say" ele ele ele ${ }^{l}$ " and put their scarf on the ground. As a result, the ongoing conflict immediately cease up by conflicting parties. There is a great consistency in the belief that curse made by women leads to misfortune among the Kembata. They often ascribe the reason of their misfortune to the act of the spirit (ayyaana). It is also believed that a curse hurts the descendants of the cursed up to seven generations. However, the Kembata believe that curse harms if and only if it is morally justified. It does not hurt the innocent person. The verdict whether or not the cursed person is innocent in the hands of the spirit or/ and Magana $^{2}$ in the name of which the curse is pronounced. In general, curse is the ultimate power that deserves social value that the Kembata use to enforce the value and law of the society (Abebe et al., 2015).

\section{The Role of Women's in Indigenous Conflict resolution in Amhara Region}

Women play different roles in addressing conflicts either along with men or alone and the male based institutions address conflicts in equal basis irrespective of sex and other differences. They, at least, play indirect roles in supporting, advising and condemning men in the peace process and in teaching children and women in the families and the villages about the importance of peace. In some communities, women serve as the symbol of peace (Kiya, 2013; Merhatsdik, 2011; Tolosa, 2011 cited in Mekuanit, 2015). Meron (2010) conducted a study on "Ye Shakoch Chilot (the court of the Sheikhs): A traditional institution of conflict resolution in Oromia zone of Amhara regional state, Ethiopia. The finding of the study revealed that traditional institution of conflict resolutions play a very significant role in day to day lives of Africa in general and Ethiopia in particular. Due to the failures in legal system to fully provide the judicial needs of the nations and matters of corruption, the state legal system officially incorporated elements from the traditional institutions of conflict resolution in the state courts.

The finding of Bantihun and Worku (2017) conducted in Simada Woreda revealed that the formal and informal conflict resolution mechanisms employed to reduced land resources conflict among Arga and Ashara local community different interpersonal conflicts in land. Due to lack of a clearly defined land policy, particularly lack of effective recognition for and protection of the customary land rights, has in turn resulted in over land since multiple 'stakeholders' with varying interests, sources of legitimacy and values have come into play to exercise claims over land, often leading to conflicts.

The study conducted by Mekuanit (2015) showed that, the roles of women in the Shimglna vary from place to place. In some areas of the district, women participate as plaintiffs, defendants and sometimes as mediators. However, in other areas, still there are women who present their issues in the Shimglna by their male relatives, and their participation as mediators is very limited. In the district, there is no any female-based institution that operates for resolving conflicts and for protecting the rights of women.

On the other hand, women play numerous roles in handling conflicts in families and neighbors. They are

\footnotetext{
${ }^{1}$ Ele ele ele - A system of Kembata women to become loud their voce and put their scarf in the ground in time of conflict resolutions.

${ }^{2}$ Magana- the hands of spirit in which the name of cursed is pronounced among Kembata community.
} 
believed to be an engine of peace in the families. Appraising the experience of the Shimglna in resolving conflicts involving women, when their involvement is low was the other major them of the study. In Meket District, while the participation of women in the Shimglna is very law, the experience of Shimglna in handling of conflicts involving women has two dimensions. The first dimension is that though women have less participation in the Shimglina as plaintiffs, defendants and mainly as mediators, the male mediators handle conflicts involving women based on equality. The other divergent view is that the less participation of women in the Shimglna has indirect impacts on the work of the Shimglna in addressing conflicts involving women (Mekuanit, 2015).

It is due to male representatives present their issues distortedly; also, due to women have secrets, which should not be told for men. Furthermore, women also fear male mediators to tell their issues vividly. Thus, male mediators misunderstood their issues; thus, make biased decisions unconsciously. Though it is rare, there are mediators who are manipulated by male counterparts in the form of bribe. The Shimglna is affected by different factors in addressing conflicts involving women. Though there have been changes, the attitude of the community to give priority to the issues of men, the paradox between the legal jurisdictions of the Shimglna to address only personal and family matters and its actual practices in addressing all kinds of conflicts and the recruitment of the well-known elders in the social courts, peace committees and other government posts results in eroding the legitimacy of mediators in the Shimglna. These factors make the issues of women as secondary (ibid).

Robert (2012) demonstrated that in Awra Amba various aspects of the social organization of the community, which is especially developed: the community structures, the economic activities, then the social relationships, through the gender equality at work, marriage, divorce and family household design, the specific and original situation of children, solidarity with the most fragile, funeral, and finally the management of internal conflicts. In Awra Amba, women account for $44 \%$ of the committee members, who can be dismissed at any time. Contrary to the rural Amhara society where funeral ceremonies are attended by a lot of people with spectacular weeping, they are attended in Awra Amba only by some people for a very short period (a few hours). These funeral rites correspond to the social and cultural system of Awra Amba, whose members do not believe in a life after the death and privilege the life on Earth. Finally, to manage the conflicts within the couples and between members of the community, several permanent bodies have been implemented. They seem very efficient to facilitate dialogue and manage conflicts in a wise manner. Generally speaking, women play a paramount role to maintain reconciliation processes for long term stability or sustaining peace through indigenous conflict resolution in Ethiopia.

Table 1: Comparison of Women's role in Conflict Resolutions (CR) and Management within Different Regions of Ethiopia

\begin{tabular}{|c|c|c|c|c|}
\hline Author & Year & Region & $\begin{array}{l}\text { Women's roles and their } \\
\text { major characteristics }\end{array}$ & $\begin{array}{l}\text { Strength and weakness of } \\
\text { women in CR }\end{array}$ \\
\hline $\begin{array}{l}\text { Tsega, } \\
\text { Robert }\end{array}$ & $\begin{array}{l}2015 \\
2012\end{array}$ & Amhara & $\begin{array}{l}\text { The role of women is high. The } \\
\text { unique characteristics of women } \\
\text { is resolve conflict } \\
\text { through"LubaBasa" (liberating } \\
\text { or making free) and "Harma- } \\
\text { Hodha" (sucking at the breast) } \\
\text { to resolve conflict. }\end{array}$ & $\begin{array}{l}\text { Strength: Women have become } \\
\text { strong in the institution both in intra } \\
\text { as well as inter-ethnic conflict } \\
\text { resolution principles and practices. } \\
\text { Weakness: Women's involvement in } \\
\text { decision making processes to CR is } \\
\text { limited. }\end{array}$ \\
\hline Solomon & 2014 & Tigray & $\begin{array}{l}\text { The role of women is low. } \\
\text { Women have a special duty in } \\
\text { the ritual process so as to prepare } \\
\text { food and local drinks for the } \\
\text { reconciliation process. }\end{array}$ & $\begin{array}{l}\text { Strength: Women exercise power } \\
\text { indirectly and informally as sisters, } \\
\text { mothers and wives within their } \\
\text { community. They have the right to } \\
\text { assist (advise) male members of their } \\
\text { lineage in times of hardship, } \\
\text { Weakness: Economic extravagancy, } \\
\text { time consuming or prolongation of } \\
\text { appointments and exclusion of } \\
\text { women from participation in conflict } \\
\text { management. }\end{array}$ \\
\hline
\end{tabular}




\begin{tabular}{|c|c|c|c|c|}
\hline Author & Year & Region & $\begin{array}{l}\text { Women's roles and their } \\
\text { major characteristics }\end{array}$ & $\begin{array}{l}\text { Strength and weakness of } \\
\text { women in CR }\end{array}$ \\
\hline $\begin{array}{l}\text { Muchie } \\
\text { and } \\
\text { Bayeh }\end{array}$ & 2015 & Oromia & $\begin{array}{l}\text { Women play a pivotal role in CR } \\
\text { and peace building. In the } \\
\text { region, women also have a } \\
\text { unique features in solving } \\
\text { conflicts among Oromo clans by } \\
\text { intervene and request for } \\
\text { reconciliation by using the } \\
\text { institution called } \\
\text { Siqqee( women institution) }\end{array}$ & $\begin{array}{l}\text { Strength: Women has involve in } \\
\text { peace promotion and peacemaking at } \\
\text { the community level. } \\
\text { Weakness: Due to multifaceted } \\
\text { nature of conflict women are not } \\
\text { forefront in reconciliation } \\
\text { mechanisms as well as before highly } \\
\text { respected and feared clan leaders. }\end{array}$ \\
\hline $\begin{array}{l}\text { Kuwee, } \\
\text { Abebe } \\
\text { etal., }\end{array}$ & $\begin{array}{l}1997, \\
2015\end{array}$ & South & $\begin{array}{l}\text { Women in play a key role in } \\
\text { averting and escalating conflict. } \\
\text { But, mostly women are } \\
\text { considered outsiders and are not } \\
\text { members of both the clan into } \\
\text { which they were born and into } \\
\text { which they were married. Their } \\
\text { unique charcatestics is that } \\
\text { resolving conflict by say" ele ele } \\
\text { ele" and put their scarf on the } \\
\text { ground }\end{array}$ & $\begin{array}{l}\text { Strength: There is a great } \\
\text { consistency in the belief that curse } \\
\text { made by women leads to misfortune } \\
\text { among the Kembata community. } \\
\text { They often ascribe the reason of their } \\
\text { misfortune to the act of the spirit } \\
\text { (ayyaana). } \\
\text { Weakness: The community calls the } \\
\text { father as abbaa (father of the house) } \\
\text { and the mother as ammaa (mother of } \\
\text { the house). Male as abbaa is the head } \\
\text { of the household who is an authority } \\
\text { figure and plays a key managerial } \\
\text { role. }\end{array}$ \\
\hline $\begin{array}{l}\text { Bamlaku } \\
\text { etal., }\end{array}$ & 2010 & Eastern(Somali) & $\begin{array}{l}\text { Women's play double roles } \\
\text { before, during and after conflicts } \\
\text { since they have special skills in } \\
\text { instigate conflict and peace } \\
\text { building. } \\
\text { Women have a unique attributes } \\
\text { in an" Abbar" system (praying } \\
\text { when there is a drought } \\
\text { conditions, war catastrophes). }\end{array}$ & $\begin{array}{l}\text { Strength: Women play roles in the } \\
\text { formation of social capital through } \\
\text { marriage and kinship relations. } \\
\text { Women have always been the center } \\
\text { for integration through marriages } \\
\text { that brought together and cemented } \\
\text { two different and distant clans. They } \\
\text { play vital roles for the sustainability } \\
\text { of peace building and conflict } \\
\text { resolution. } \\
\text { Weakness: } \\
\text { economically poor and dependent to } \\
\text { male counterpart and women are not } \\
\text { allowed to sit and participate in } \\
\text { conflict resolution formally, they } \\
\text { have the invisible hands that play } \\
\text { their role behind the scene. }\end{array}$ \\
\hline
\end{tabular}

N:B: The above listed regions in Table-one are not the only regions of Ethiopia; but it can be taken as a sample to generalize and to make comparison among regions of Ethiopia.

\section{CONCLUSIONS AND RECOMMENDATIONS}

All available mounting evidences around the world and across cultures showed that, integrating women and gender considerations into peace-building processes helps promote democracy, good governance, long-term stability and development. In order to achieve these goals, women need to be able to play a role in building and participating in the full range of decision-making institutions in their countries. These institutions, from civil society to the judicial and security sectors, must also be responsive to and informed by women's demands. In the past ten years, women's contribution to peace building and reconciliation especially in indigenous conflict resolution is quite significant despite the fact that it has not been hitherto acknowledged and documented. This is largely attributed to the traditional role of women as peacemakers and the post-conflict environment both social and political which was conducive to enhance women's involvement in the peace and reconciliation process.

However, great hurdles remain to be overcome if women's role in this process is to be maximized. The international community can help keep women's roles and recommendations on the table through further support and training for the women's organizations that make up the coalition, and by demanding attention to the coalition's demands in the mediation. In a world of continuing instability and violence, the implementation of 
cooperative approaches to peace and security is urgently needed. The equal access and full participation of women in power structures and their full involvement in all efforts for the prevention and resolution of conflicts are essential for the maintenance and promotion of peace and security.

Gender equality and women's empowerment are central to global peace and security. Hence, sustainable resolutions to conflict should be built on the involvement of women in decision-making, the prevention of sexual violence in conflict, and peace processes that take into account the needs and experiences of both men and women and the different impacts that conflict has on them. Similarly to encourage women to participate fully in decision-making events; the revitalization and appreciation of the indigenous community institutions. This could be possible through institutional socialization of the younger generations within their indigenous cultures. Such socialization should include the preservation of positive moral and cultural values, and the identifying of elderly resource persons who have ample experience in their traditional customary law so as to document and transfer it to the next generation. Based on the above findings, sharing experiences with other communities and ethnic groups, challenging gender inequality and discrimination, reducing social barriers and patriarchy, building institutional linkages between the formal court and the indigenous institutions, promoting and acknowledging indigenous culture and values are forwarded as a baseline recommendation to manage conflict effectively and to peace building in the country as a whole.

\section{REFERENCES}

Abebe Demewoz Mengesha, Samson Seid Yesuf, and Tessema Gebre(2015). "Indigenous Conflict Resolution Mechanisms among the Kembata Society." American Journal of Educational Research, vol. 3, no. 2: 225242. doi: 10.12691/education-3-2-17.

Abebe Demewoz Mengesha (2016). The Role of Sidama Indigenous Institutions in Conflict Resolution: In the Case of Dalle Woreda, Southern Ethiopia. American Journal of Sociological Research, 6(1): 10-26 DOI: 10.5923/j.sociology.20160601.02

Africa Development Bank(2008). CHAPTER 2: The consequences of conflict file://C:/ Users/toshiba/Desktop/conflct\%20pdf/African\%20/Development\%20Report\%202008.2009 03 Chapter\%2 0 II(2).pdf

Ambaye Ogato (2008). Traditional Conflict Resolution Mechanisms: the case of Sidama. In Hannan, T \&Tarekegn, A. (eds) making peace in Ethiopia: Five cases of traditional mechanisms for conflict resolution. (pp. 101-120): Addis Ababa, peace and Development committee.

Bamlaku T., Tadesse,B., Beyene, F,. (2010). Women in Conflict and indigenous conflict resolution among the Issa and Gurgura clans of Somali in Eastern Ethiopia. African Journal on Conflict Resolution, volume 10, Number 1, p. 85-110

Bantihun A, Worku M (2017). Inter Personal Conflict Resolution Methods on Case of Land in Semada Werda, South Gonder Ethiopia. Arts Social Sci J 8: 315. doi: 10.4172/2151-6200.1000315

Best, S.G (2004). The Methods of Conflict Resolution and Transformation. In Best, S.G.(ed.). Introduction to Peace and conflict studies in West Africa (pp.93-115) (PP. 93-115. Ibadan: spectrum Books ltd.

Birhanu Mekonnen (2010).Conflict Management and Peacemaking at Community level: the case of NegedeWoyto. MA thesis, Addis Ababa University (Unpublished).

Chandan, J.S (1995). Management: Theory and Practice. New Delhi: VBIKS publishing House Pvt. Ltd

Common wealth of Australia (2015). DFAT, Women, Peace and Security: DFAT's implementation of UN Security Council Resolution 1325, February 2015. Women, Peace and Security: DFAT's implementation of UN Security Council Resolution 132, Department of Foreign Affairs

Dragos Marian (2012). Mediation - a Method to Resolve Conflicts Without Going to Justice, Revista Română de Statistică - Supliment Trim IV/2012,,Dimitrie Cantemir” Christian University

Elster, Jon(1989). The cement of society: A study of social order. Cambridge University Press

Endale Alemu H (2014). Factors that affect Women Participation in Leadership and Decision Making Position, Asian Journal of Humanity, Art and Literature, Volume 1, No 2 (2014)

Eshleman, J.R. \& Wilson, S.J (1995). The Family (Canadian edition).Ontario: Allyn and Bacon.

Fisher R( 2000). Source of Conflict and Methods of Conflict Resolution. International Peace and Conflict Resolution school of International Service: The American University. Retrieved on September, 2010, from http:// www. Aupeace.org /

Jens Allwood.1993. Types of conflict and conflict handling in an academic seminar in $\mathrm{j}$. hultberg (ed.) new genres in science studies, Dept of the theory of Science, University of Göteborg

John Mutamba, and Jeanne Izabiliza (2005). The national unity and reconciliation commission (nurc), the role of women in reconciliation and peace building in rwanda: ten years after genocide 1994-2004 : contributions, challenges and way forward.

Kifle Gashie (2007). Traditional mechanisms of conflict transformation among the rural Hadiya community: A social psychological analysis. MA Thesis, AAU (unpublished). 
Kwaku Osei-Hwedie and Morena J. Rankopo (n.d). Chapter 3: Indigenous Conflict Resolution in Africa: The Case of Ghana and Botswana, University of Botswana.

Meaza Ashenafi (2009). Factors Affecting Women Participation in Politics and Decision making. A Dissertation of MA Thesis

Mekuanint Tesfaw(2015). Ethiopian Women; Agents and Subjects in the Shimglna (a Customary Conflict Resolution Institution): Amharas' Experience in Meket District, North Wollo Zone, Sociology and Anthropology 3(2): 95-103 http://www.hrpub.org DOI: 10.13189/sa.2015.030204

Messele Madda (2008). The role of Elders in resolving conflicts: The case of Walayta people of southern Ethiopia. In Hannan, T \&Tarekegn, A. (eds) making peace in Ethiopia: Five cases of traditional mechanisms for conflict resolution. (pp. 21-47) Addis Ababa, Peace and Development Committee.

Meron Zeleke (2010). Ye Shakoch Chilot (the court of the sheikhs): A traditional institution of conflict resolution in Oromiya zone of Amhara regional state, Ethiopia. African Journal on Conflict Resolution, 10 (1), pp.63-84

Mesfin Woldemariam (1999). The horn of Africa: conflict and poverty. Addis Ababa: commercial printing press OSSREA.

Mohamed, Abdi M (2003). The role of Somali women in the search for peace. In: UNESCO 2003, pp. 75-110.

Muchie Z, and Bayeh E (2015) Traditional Conflict Resolution Mechanisms among Ambo Woreda Communities. J Pol Sci Pub Aff 3: 147. doi:10.4172/2332-0761.1000147

Olsen, D.H \&Defrain, J (2000). Marriage and Family: Diversity and Strengths (3rded.).California: Mayfield Publishing Company

Rahim M A (1992). Managing conflict in organizations New York: Praeger

Robert Joumard (2012). Awra Amba, a current experiment of utopian socialism. [Research Report] Attac. 2012. $<$ hal- 00916551>

Sheriff F. Folarin (N.d). Chapter Three: Types and Causes of Conflict

Solomon Berhane(2014). Indigenous Democracy: Alternative Conflict Management Mechanisms Among Tigray People, The Experiences of Erob, Community, Journal of Scince \& Development 2(2), 101-122.

Tarekegn Adebo (2008). Traditional mechanisms of conflict resolution (TMCR) in Ethiopia, meaning, values, structures, procedures and outcome. In Hannan, T \&Tarekegn, A. (eds), Making peace in Ethiopia: Five cases of traditional mechanisms for conflict resolution. (pp. 9-20) Addis Journal of Science \& Development 2(2) 2014

Tsega Endalew (2005). Luba Basa and Harma-Hodha: Traditional mechanisms for conflict Resolution in Metekel, West Gojjam. Proceedings of the national workshop of the Ethiopia chapter of OSSREA (pp. 130155): Addis Ababa.

Tsegay Berhe(2003). An Etho-Historical survey of the Erob Agri-pastoralists of North Eastern Tigray (Ethiopia). Retrieved on October 2010 from http://www.irrob.org/articles-on-irob.html

Uthman Hassen (2008). The role of Abegar (Divine Father) in conflict Resolution: The case of Northern Wollo. In Hannan, T \&Tarekegn, A. (eds.) making peace in Ethiopia: Five cases of traditional mechanisms for conflict resolution (pp.78-100), Addis Ababa, Peace and Development committee.

Yasin Mohammed (2010). An exploration of the "Abegar system" A traditional resolution mechanism in South Wollo. MA Thesis, AAU (Unpublished) 